\title{
En samtale om lov og ret i I.R. Iran
}

\section{Ditlev Tamm}

\section{Forkortelsen I.R. - islamisk republik - er afgøren- de for forståelse af offentlige institutioner i Iran, og uden forståelse for den iranske revolutions principper og islams plads som rettesnor er det heller ikke muligt at forstå det iranske retssystem}

I april var en gruppe fra Udenrigspolitisk Selskab på studietur til Iran. En sådan rejse giver anledning til at tænke over meget både i Iran og hjemme, og for mig som jurist var det naturligt at prøve at få et indtryk af retssystemet, der på papiret ser ganske tilforladeligt ud, men som unægtelig, når man går sagen efter i detaljer, er ganske særegent. Helst ville jeg have besøgt en domstol, men det kunne nu ikke lade sig gøre.

Til gengæld stillede en institution, der svarer til den danske domstolsstyrelse, sig velvilligt til disposition, og jeg fik mulighed for at føre en godt en time lang samtale med direktøren for 'Judiciary of I.R. Iran's' internationale kontor. Han forærede mig en lille pjece om det iranske retssystem og teksten til et par taler holdt af den øverste leder af domstolsvæsenet, der i stærkt aggressive vendinger priste det iranske system baseret på islam og revolutionens resultater.

\section{Islam som rettesnor}

Hvordan det hele egentlig foregår, er svært at vide på grundlag af en sådan samtale og lidt spredt læsning. En ting er imidlertid sikker, at uden forståelse for den iranske revolutions principper og islams plads som rettesnor, fatter man ingen ting af det iranske retssystem.

Lederen af retsvæsenet udpeges af Den Øverste Leder. I den forstand er retssystemet indordnet i det intrikate iranske system af statsorganer, hvis legitimitet på en eller anden 
måde afledes af Den $\emptyset$ verste Leder og dermed er forbundet med religionen. Iran er en islamisk republik, og det betyder for retsvæsenet, at islamisk ret, som den kan læses i Koranen med den tilhørende tradition i den shiitiske udgave, spiller en helt afgørende rolle. Egentlig er der en modsætning mellem islam og staten, men i Iran er denne modsætning ophævet i landets selvforståelse, og den islamiske republik fremstår i denne som et ideelt system, som andre nationer gerne vil indføre, når de først har forstået det.

Selve det retlige apparat minder i det ydre om vores. Domstolene findes på lokalt niveau, som appelretter regionalt, og der er en Højesteret. Irans Højesteret fungerer lidt anderledes end den danske, nemlig i flere afdelinger med forskellige specialer, og retten henviser en sag til en ny retssag, hvis den er uenig $i$ en dom.

Den iranske domstolsstyrelse overvåger domstole $\mathrm{og}$ anklagemyndighed og er den, der afgør dommeres avancement, der som regel er ret automatisk. Domstolsstyrelsen tager sig også af dommeruddannelsen, som formentlig ikke fejler noget med hensyn til grundighed.

Lidt usædvanligt for vore forhold er de særlige revolutionsdomstole, men dem skulle jeg nu ikke bekymre mig om, sagde direktøren i domstolsstyrelsen, for der gjaldt samme regler som for andre domstole, en måske ikke helt betryggende be- mærkning for den, der havde hørt om revolutionsdomstolenes lynhurtige procedure i alvorlige sager om, hvad der anses som statens sikkerhed. En anden særegenhed er anvendelsen af dommere med en teologisk uddannelse i en del sager. Der er særlige familiedomstole og ungdomsdomstole.

\section{Alternative straffe}

Islamisk strafferet er forbundet med forestillingen om dødsstraf, stening, afhugning af hænder og andre former for lemlæstelse. Det er virkelighed i Iran. Fængselsstraffe undgås helst, og man foretrækker alternativer til fængselsstraf, der har en noget mere alternativ karakter, end hvad vi er vant til.

Jeg skulle nu ikke være bekymret, sagde min samtalepartner i Domstolsstyrelsen. Stening er ikke noget, der anvendes ofte, og i de senere år havde der kun været ganske få sager. Det er jo sådan, at stening for ægteskabsbrud ikke er foreskrevet i Koranen, men i overleveringerne om Muhammed, de såkaldte hadith, findes en beretning om, at profeten anbefalede stening af en mand, der blev ved med at fortælle, at han havde begået ægteskabsbrud. Der skal altså tilståelse til, og dommerne er instrueret om at indskærpe anklagede konsekvensen af, at de ikke benægter en sådan forbrydelse.

Afhugning af hånden anvendes ikke som straf for tyveri. Højst bliver 
de yderste led af tre finger afhugget, blev jeg beroligende fortalt, da talen faldt på tyveristraffen.

Og dødsstraf er heller ikke noget, som den offentlige anklager gør meget for at få nogen idømt. I tilfælde af drab kan den forurettede familie gå i forbøn eller undlade at kræve dødsstraf, og i sådanne tilfælde kan sagen bilægges på anden måde. Heller ikke når det drejer sig om seksuelle afvigelser, er der megen stemning for dødsstraf. Der skal noget mere til, fx voldtægt eller anden tvang for, at anklagemyndigheden vil skride ind, fik jeg at vide.

\section{Forlig frem for domstolsafgørelser}

Overhovedet anvendes gerne i Iran aftalte ordninger i form af forlig frem for domstolsafgørelser. Islamisk ret er ikke særlig domstolsorienteret, men i virkeligheden udtryk for en tolkning af netop Koranen.

Iransk lovgivning bedømmes af et råd med henblik på at konstatere, om den er overensstemmende med Koranen og islamisk tradition i den shiitiske udgave. Det betyder, at en del af de principper, som vi kender, ikke tillægges betydning. Der straffes efter religiøse principper, og hele grundtanken bag retssystemet er opnåelse af den særlige retfærdighed, som Koranen anses som et ud- tryk for. Garanten for det er Den $\varnothing$ verste Leder.

Domstolene er kun uafhængige af den udøvende magt inden for netop den ramme, der sættes af Den Øverste Leder, som er den, der personificerer ånden i den islamiske republik.

Ser man bort fra strafferetten, hvor islamiske principper er så karakteristiske, er der formentlig meget $i$ iransk retsvæsen, der vil minde om systemet $i$ andre lande, det gælder både dommere og advokater eller typen af sager. Den afgørende forskel er imidlertid ånden i det iranske retsvæsen, der lige som ånden i andre institutioner, vi mødte på studieturen, er dybt præget af loyalitet over for revolutionen og de principper, der ligger til grund for den islamiske republik.

Forkortelsen I.R. - islamisk republik - er afgørende for forståelse af offentlige institutioner i Iran. Retssystemet har sin rolle i gennemførelsen af den islamiske republiks principper. Det er svært at forstå og gennemskue dette system, men uden forståelse for, at man er nødt til at prøve at forstå dette system for at forstå Iran i dag, forstår man som sagt slet ingen ting.

Ditlev Tamm, dr. jur. et phil., professor ved Det Juridiske Fakultet, Københavns Universitet. 